\title{
Lost in the Weeds?: A Comprehensive Guide to Florida's Many Non-Native Plant Lists ${ }^{1}$
}

\author{
Deah Lieurance and Lyn A. Gettys ${ }^{2}$
}

Florida is a national and global hot spot for non-native, invasive species. Invasive species are a threat to the environment, economy, and human health. Because researchers and land managers in Florida have been dealing with invasive species for decades, there is an abundance of resources available to the public regarding invasive species. Sometimes, the volume of available information can be confusing. There are five different primary lists of non-native plant species that are referenced in Florida: 1. The Federal Noxious Weed List, 2. The Florida Noxious Weed List, 3. The Florida Prohibited Aquatic Plant List, 4. The Florida Exotic Pest Plant Council (FLEPPC) Plant List, and 5. The UF/IFAS Assessment of Non-Native Plants. This document aims to inform the general public, land managers, researchers, local and state policy makers, and others who seek guidance in accessing regulatory and nonregulatory non-native plant lists in the state of Florida. This publication explains the origins of the lists, meaning of inclusion on a particular list, and ways to access each of the lists.

Non-native, invasive species pose a significant threat to the environment through degradation of habitat and reduction of species diversity and to the economy through monetary losses in agriculture and recreation and the tremendous cost to manage widespread invaders. Florida is especially susceptible to biological invasions due to its tropical/ subtropical climate, peninsular shape, and the number of intentional (via horticulture and agriculture) and unintentional (via trade and tourism) species introductions.
Researchers and land managers have been dealing with invasive plant species for many years. In fact, the UF/IFAS Center for Aquatic and Invasive Plants was established in 1979. Because Florida has such a long history of handling problems associated with invasive species, the state is also rich in resources specific to invasive species (e.g., identification, management, alternatives to invaders). The downside to an abundance of available information is that it can be confusing and sometimes overwhelming to know what resources are best for your situation and how to access them. In particular, Florida has five primary lists that categorize non-native, invasive plants and many other minor lists (e.g., Florida Invasive Species Partnership Early Detection Rapid Response lists, UF's Florida-Friendly Landscaping $^{\text {ma }}$ Plant Guide, and Florida Natural Areas Inventory Invasive Species Information Descriptions). This document focuses on five primary lists applicable to Florida and aims to eliminate some confusion about the nature of these lists, the meaning of inclusion on a particular list, and the way to access each list.

1. The Federal Noxious Weed Act (FNWA) enacted in 1975 established a federal program to control the spread of noxious weeds in the United States. The FNWA granted the Secretary of Agriculture the authority to categorize plants as noxious weeds, thus creating the Federal Noxious Weed List. Once a plant is placed on the federal list, all interstate or foreign movement of any living part of a listed species is prohibited (except under permit), consequently limiting its transportation across

1. This document is SS-AGR-436, one of a series of the Agronomy Department, UF/IFAS Extension. Original publication date August 2019. Visit the EDIS website at https://edis.ifas.ufl.edu for the currently supported version of this publication.

2. Deah Lieurance, assistant Extension scientist, UF/IFAS Assessment coordinator, Agronomy Department; and Lyn A. Gettys, associate professor, Agronomy Department, UF/IFAS Fort Lauderdale Research and Education Center; UF/IFAS Extension, Gainesville, FL 32611.

The Institute of Food and Agricultural Sciences (IFAS) is an Equal Opportunity Institution authorized to provide research, educational information and other services

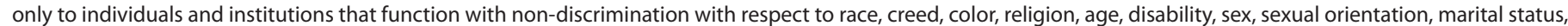

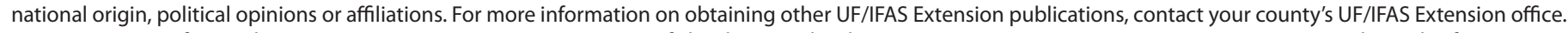
U.S. Department of Agriculture, UF/IFAS Extension Service, University of Florida, IFAS, Florida A \& M University Cooperative Extension Program, and Boards of County Commissioners Cooperating. Nick T. Place, dean for UF/IFAS Extension. 
state lines. The FNWA was amended in 1990 to include provisions requiring federal land management agencies (e.g., Bureau of Land Management, National Park Service, U.S. Fish and Wildlife) to take appropriate measures to reduce the spread of invasive species. In 2000, most of the FNWA was incorporated into the Plant Protection Act, which is the most current legislation regulating invasive plant species on a national scale. With each of these amendments and updates, the interstate movement of listed species is still prohibited without a permit from the United States Department of Agriculture Animal and Plant Health Inspection Service Plant Protection and Quarantine (USDA APHIS PPQ). Penalties for those who violate the law include the seizure of plant material and the implementation of misdemeanor fines (United States Government Publishing Office 2019).

The Federal Noxious Weed List is currently managed by USDA APHIS PPQ and was last updated in 2010 (minor changes were included in 2017). The list includes a number of species found in Florida, including cogongrass (Imperata cylindrica), hydrilla (Hydrilla verticillata), Old World climbing fern (Lygodium microphyllum), tropical soda apple (Solanum viarum), melaleuca (Melaleuca quinquenervia), and giant salvinia (Salvinia molesta) (Figure 1). For more information, you can access the Plant Protection Act online: https://www.govinfo.gov/content/ pkg/PLAW-106publ224/html/PLAW-106publ224.htm.

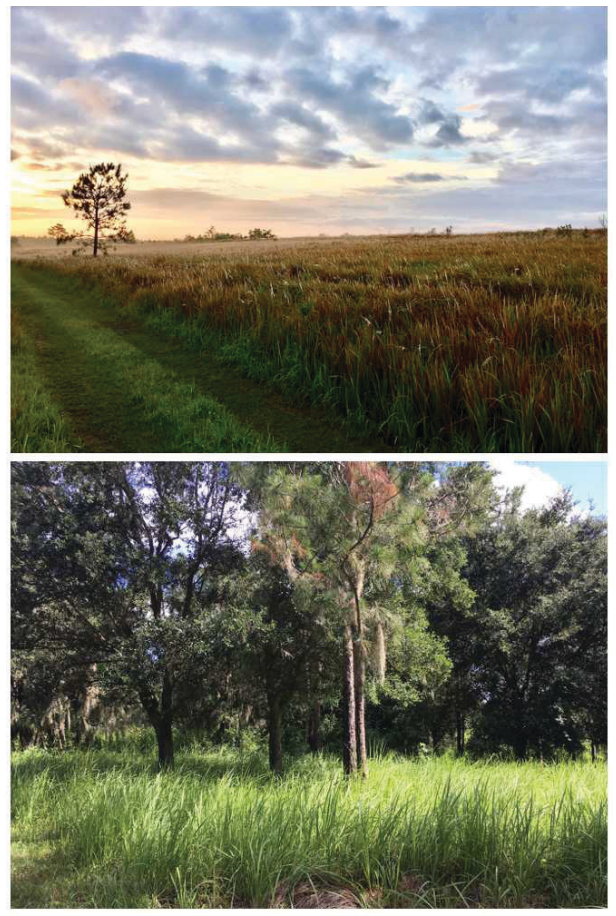

Figure 1. Two examples of cogongrass (Imperata cylindrica) invasions in central Florida, one in an open field and the second in a forested natural area. Cogongrass is a federally listed noxious weed. All interstate or foreign movement of this listed species is prohibited. Credits: Drew Hiatt and Taylor Clark, UF/IFAS
2. The Florida Noxious Weed List is a state-specific counterpart to the Federal Noxious Weed List. It was created in 1993 and has been amended multiple times to add new species that have been identified as invasive. The Florida Department of Agriculture and Consumer Services (FDACS) oversees this list (including the addition of new species and exemptions for agronomic and horticultural cultivars of listed species); the FDACS Division of Plant Industry (DPI) enforces regulations (inspections and fines). Similar to federally listed species, "it is unlawful to introduce, multiply, possess, move or release any noxious weed" without a permit (FDACS 2019a). FDACS defines a noxious weed as:

"Any living stage of a parasitic or other plant which may be a serious agricultural threat in Florida; have a negative impact on endangered, threatened, or commercially exploited plant species; or if the plant is a naturalized plant that disrupts naturally occurring native plant communities" (FDACS 2019b).

This list includes three genera of parasitic weeds (Aeginetia spp., Alectra spp., and non-native Cuscuta spp.), and more than 70 species including air potato (Dioscorea bulbifera) (Figure 2), Brazilian peppertree (Schinus terebinthifolius), coral ardisia (Ardisia crenata), and lead tree (Leucaena leucocephala). Historically, the Florida Noxious Weed List has been limited to upland species, but invasive aquatic plants such as crested and yellow floatingheart (Nymphoides cristata and N. peltata) are now included on this list. You can access the full list here.

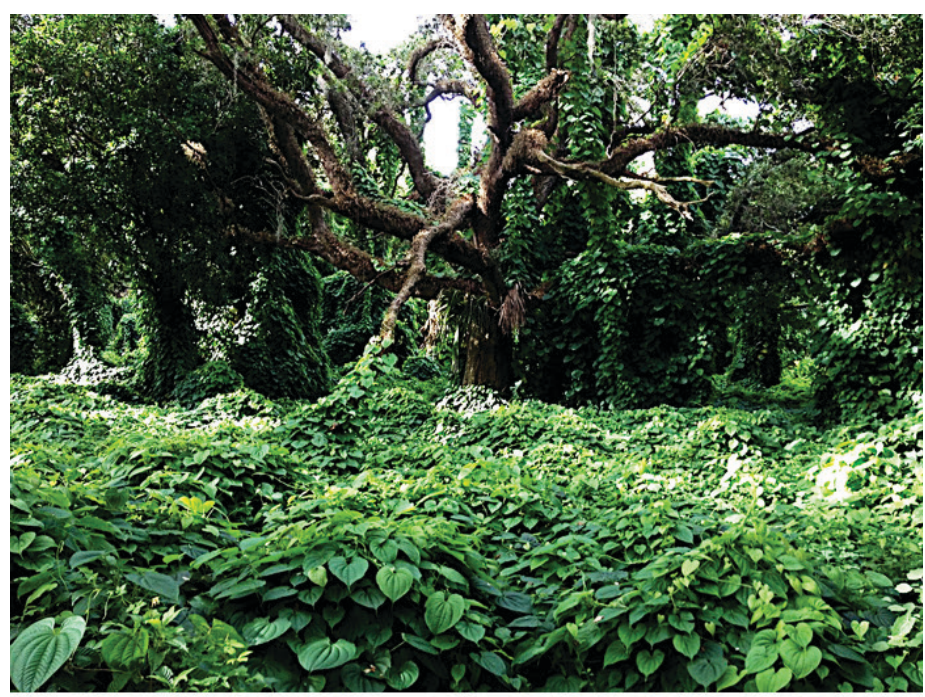

Figure 2. Air potato (Dioscorea bulbifera) invasion in south Florida (Broward County). Air potato is on the Florida Noxious Weed List. FDACS DPI oversees and enforces this list.

Credits: Deah Lieurance, UF/IFAS

3. The Florida Prohibited Aquatic Plant List was created in 1986 and last amended in 1993. Originally, this list was administered by the Florida Department of 
Environmental Protection (DEP), but it is currently under the jurisdiction of FDACS. According to FDACS Rule 5B-64, "The Department of Agriculture and Consumer Services, Bureau of Plant and Apiary Inspection shall administer the aquatic plant management program of the state as may be necessary for the eradication, control, or prevention of the introduction and dissemination of noxious or prohibited aquatic plants through the importation, transportation, non-nursery cultivation, collection, sale, or possession of aquatic plants" (FDACS 2019c). There are two classes in the Florida Prohibited Aquatic Plant List: Class I Prohibited Aquatic plants adhere to the same rules that apply to plants on the Florida Noxious Weed List, but Class II plants can be grown by nurseries, provided the nurseries have a state-issued permit and only sell the plants to customers outside Florida. As with plants on the Federal and Florida Noxious Weed Lists, it is illegal to cultivate, grow, sell, trade, or move Category I plants (FDACS 2019c). Penalties for violating this rule include seizure and destruction without compensation of any regulated plant and revegetation where excessive collecting has resulted in diminished habitat. Violators may be found guilty of a second-degree misdemeanor and fined.

A number of Class I plants-including Australian pine (Casuarina spp.), melaleuca, and hydrilla-are also on the Federal Noxious Weed List. However, some Class I plants are only major problems in Florida, including alligatorweed (Alternanthera philoxeroides) and water hyacinth (Eichhornia crassipes) (Figure 3). You can access the Florida Prohibited Aquatic Plants List here.

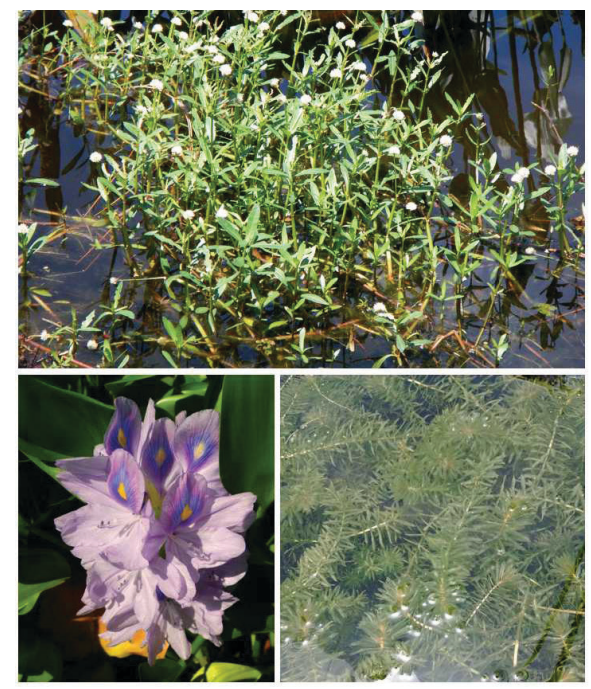

Figure 3. Alligatorweed (Alternanthera philoxeroides), water hyacinth (Eichhornia crassipes), and hydrilla (Hydrilla verticillata). All three species are on the Florida Prohibited Aquatic Plant List, and hydrilla is also on the Federal Noxious Weed List. FDACS DPI oversees and enforces the Florida Prohibited Aquatic Plant List.

Credits: Lyn A. Gettys, UF/IFAS
4. The Florida Exotic Pest Plant Council, a nonprofit organization established in 1984, provides a list of Florida's most invasive plants. The mission of FLEPPC is "to support the management of invasive exotic plants in Florida's natural areas by providing a forum for the exchange of scientific, educational and technical information." One way the organization aims to promote that mission is through the FLEPPC Plant List. The Plant List Committee, which consists of biologists, botanists, ecologists, and land managers who regularly consider the addition of new species and any changes in the invasive status of species already included, develops and maintains this list. The FLEPPC list is nonregulatory but has been incorporated into many state and regional invasive plant management procedures. Listings are based on scientific information and field observations. A consensus must also be reached first by the Plant List Committee and then by the Board of Directors before a species is officially added to the list. This list is revised every two years.

Species on the FLEPPC Plant List are grouped into two categories based on the level of ecological impacts the plant causes. Category I invasive plants have been shown to alter "native plant communities by displacing native species, changing community structures or ecological functions, or hybridizing with natives" (FLEPPC 2019). This conclusion relies on documented evidence of ecological damage; it does not rely on the economic severity or geographic range of the invasion. Category II invasive species are plants that have "increased in abundance or frequency but have not yet altered Florida plant communities to the extent shown by Category I species" (FLEPPC 2019). These species may be promoted to Category I species if they become more invasive and more ecological damage is observed. Many species appear on the FLEPPC list as well as on the federal and state lists (indicated in the "Govt. List" column). The list includes a "Zone" column to document where a particular plant is likely to have the most serious impacts (north, central, or south Florida).

\section{The UF/IFAS Assessment of Non-Native Plants in} Florida's Natural Areas (hereafter referred to as the UF/ IFAS Assessment) uses literature-based assessment tools to evaluate the invasion status or risk of non-native species that occur in the state, new species proposed for introduction, and novel agronomic and horticultural selections, hybrids, and cultivars. The Status Assessment (SA) is used to evaluate species currently present in the state and incorporates information (ecological impacts and management difficulty) from experts (land managers, 
scientists, etc.) to complete the assessment. The Predictive Tool (PT) is a risk-assessment model used to predict the potential or risk a species has to become invasive within the state. Cultivars are evaluated with the Infraspecific Taxon Protocol (ITP), and data are provided by the breeders who develop the cultivars. Results from these assessments are used in the cultivar release process at UF/ IFAS. Unlike the previous lists, the UF/IFAS Assessment provides conclusions for non-native species, both invasive and noninvasive (Figure 4). The UF/IFAS Assessment provides the following possible recommendations:

- Not considered a problem species at this time, may be recommended (SA, ITP)

- Low Invasion Risk, may be recommended (PT)

- Caution, may be recommended, but manage to prevent escape (SA, ITP)

- Evaluate Further, may be recommended, but manage to prevent escape (PT)

- Invasive and not recommended (SA, ITP)

- High Risk and not recommended (PT)

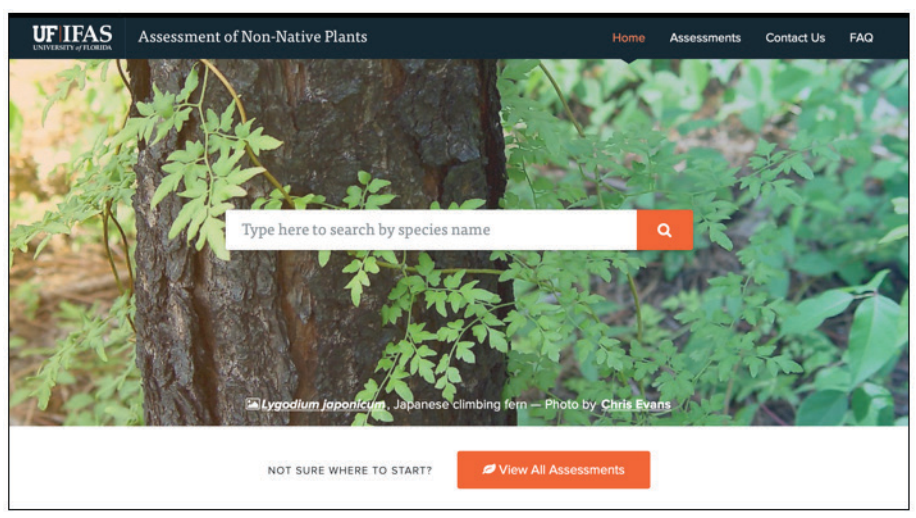

Figure 4. The UF/IFAS Assessment website where you can access assessment results for approximately 900 non-native species. Species on this list include those that are determined to be "invasive" or "highrisk for invasion," "caution (manage to prevent escape)" or "evaluate further," and "OK to recommend or low-risk for invasion." The UF/IFAS Assessment list provides more detailed information on the status of a species (https://assessment.ifas.ufl.edu).

Credits: UF/IFAS

Occasionally, there are circumstances where the UF/IFAS Invasive Plant Working Group may develop "Specified and Limited Uses" for invasive or high-risk species. In these specific cases, the species may be recommended if these guidelines are followed (see conclusions for coconut palm in south Florida). Additionally, there are species in the database that have been evaluated with more than one of these tools. In these instances, more than one conclusion is provided. However, instructions indicate the most conservative conclusion must be followed.
Even though the UF/IFAS Assessment conclusions are nonregulatory for the general public, researchers and other personnel at UF/IFAS are prohibited from recommending the use of an "Invasive" or "High-Risk" species. The public can also use the noninvasive conclusions (i.e., "Not considered a problem species at this time" and "Low Invasion Risk") in this database to create a white list of plants that should be well-behaved in the landscape and may be included in plantings. While this is not a guarantee the species will not become invasive in the future, it should be noted that the UF/IFAS Assessment regularly reevaluates species to track any changes in behavior. Currently, there are approximately 900 species in the UF/ IFAS Assessment database. If there is a non-native species missing from the database, you can request an evaluation from the website. More information about how the UF/ IFAS Assessment works and what types of data are used to reach a conclusion can be found here: http://edis.ifas. ufl.edu/ag376.

\section{Conclusion}

Florida is a hot spot in the nation and the world for nonnative, invasive species. Because researchers and land managers have been dealing with invasive species for decades, there is an abundance of resources available to the public regarding invasive species. Navigating these resources can be confusing and sometimes overwhelming for the public. Florida has five primary lists that categorize non-native, invasive plants; it is not enough to say that a particular plant is "on the list." Of the five lists most commonly used to classify non-native plants in Florida, three are regulatory (Federal Noxious Weed List, Florida Noxious Weed List, and Florida Prohibited Aquatic Plant List) and two (FLEPPC Plant List and UF/IFAS Assessment) make recommendations based on current knowledge of distribution, ecological impacts, and management difficulty. See Table 1 for more information on regulation status, suggested users, and direct links to the plant lists. Improper handling of state or federally listed species could result in legal consequences. Category I and II species listed on the FLEPPC Plant List and "Invasive" or "High-Risk" and "Caution" or "ModerateRisk/Evaluate" species included in the UF/IFAS Assessment should be avoided due to their invasive status or potential. It is imperative to make the right choices when it comes to non-native species. Using these lists correctly can reduce non-native plant invasions in Florida and throughout the Southeast. If you have questions about non-native plants in your area, contact your local UF/IFAS Extension agent. 


\section{Glossary}

Non-native species-Refers to a species (or subspecies, cultivar, selection, etc.) introduced (intentionally or accidentally) outside its natural past or present distribution (synonyms: exotic, alien).

Naturalized species-A non-native plant that does not need human help to reproduce and maintain itself over time in an area where it is not native (synonym: casual).

Invasive species-A species that is non-native (or alien) to the ecosystem under consideration and whose introduction causes or is likely to cause economic or environmental harm or harm to human health. Invasive species can be plants, animals, and other organisms (e.g., microbes).

Weed-A weed is a plant (native or non-native) that is not valued in the place where it is growing. Any plant that poses a major threat to agriculture and/or natural ecosystems within the United States.

Noxious weed-Legal context (from Federal Plant Protection Act): "Any plant or plant product that can directly or indirectly injure or cause damage to crops (including nursery stock or plant products), livestock, poultry, or other interests of agriculture, irrigation, navigation, the natural resources of the United States, the public health, or the environment" (United States Department of Agriculture 2019).

Natural area-Areas (public or private) with designated management objectives that include the conservation of native biodiversity.

\section{References}

Animal and Plant Health Inspection Service. 2019. "Federal Noxious Weeds." Accessed April 2, 2019. https://www.aphis. usda.gov

Florida Department of Agriculture and Consumer Services, Division of Plant Industry. 2019a. “5B-57.007 Noxious Weed List.” Accessed April 2, 2019. https://www.flrules.org/ gateway/ChapterHome.asp?Chapter $=5 \mathrm{~B}-57$

Florida Department of Agriculture and Consumer Services, Division of Plant Industry. 2019b. "Noxious Weeds."

Accessed April 2, 2019. https://www.freshfromflorida.com/ Divisions-Offices/Plant-Industry/Bureaus-and-Services/ Bureau-of-Entomology-Nematology-Plant-Pathology/ Botany/Noxious-Weeds

Florida Department of Agriculture and Consumer Services, Division of Plant Industry. 2019c. "5B-64.011 Prohibited Aquatic Plants.” Accessed April 2, 2019. https://www.flrules. org/gateway/ChapterHome.asp?Chapter=5B-64

Florida Exotic Pest Plant Council. 2019. "Florida Exotic Pest Plant Council Invasive Plant Lists." Accessed April 2, 2019. https://www.fleppc.org

United States Department of Agriculture, Animal and Plant Health Inspection Service. 2019. "Federal Noxious Weeds." Accessed April 2, 2019. https://www.aphis.usda.gov

United States Government Publishing Office. 2019. “The Federal Noxious Weed Act.” Accessed April 2, 2019. https://www.govinfo.gov/content/pkg/STATUTE-88/pdf/ STATUTE-88-Pg2148.pdf 
Table 1. Additional information on the five primary non-native plant lists used in Florida with regulation status, suggested users, and links to access the lists.

\begin{tabular}{|c|c|c|c|}
\hline Resource & $\begin{array}{l}\text { Regulatory } \\
\text { (Y/N) }\end{array}$ & Suggested Users & Link \\
\hline $\begin{array}{l}\text { Federal Noxious } \\
\text { Weed List }\end{array}$ & Y & $\begin{array}{l}\text { UF/IFAS faculty and staff, Extension programs } \\
\text { (UF/IFAS Extension Florida Master Gardener } \\
\text { Volunteer Program, Florida-Friendly } \\
\text { Landscaping }^{\text {TM }} \text { Program), land managers, } \\
\text { federal/state/local agencies, general public }\end{array}$ & $\begin{array}{l}\text { https://www.aphis.usda.gov/plant_health/plant_pest_info/ } \\
\text { weeds/downloads/weedlist.pdf }\end{array}$ \\
\hline $\begin{array}{l}\text { Florida Noxious } \\
\text { Weed List }\end{array}$ & Y & $\begin{array}{l}\text { UF/IFAS faculty and staff, Extension programs } \\
\text { (Florida Master Gardener Volunteer Program, } \\
\text { Florida-Friendly Landscaping } \\
\text { land Program), } \\
\text { general public }\end{array}$ & https://www.flrules.org/gateway/ruleNo.asp?id=5B-57.007 \\
\hline $\begin{array}{l}\text { Florida Prohibited } \\
\text { Aquatic Plant List }\end{array}$ & Y & $\begin{array}{l}\text { UF/IFAS faculty and staff, Extension programs } \\
\text { (Florida Master Gardener Volunteer Program, } \\
\text { Florida-Friendly Landscaping }{ }^{\text {TM }} \text { Program), } \\
\text { land managers, federal/state/local agencies, } \\
\text { general public }\end{array}$ & https://www.flrules.org/gateway/RuleNo.asp?id=5B-64.011 \\
\hline FLEPPC Plant List & $\mathrm{N}$ & $\begin{array}{l}\text { Land managers, federal/state/local agencies, } \\
\text { general public }\end{array}$ & https://www.fleppc.org/list/list.htm \\
\hline $\begin{array}{l}\text { UF/IFAS } \\
\text { Assessment }\end{array}$ & $\mathrm{N}^{*}$ & $\begin{array}{l}\text { UF/IFAS faculty and staff, Extension programs } \\
\text { (Florida Master Gardener Volunteer Program, } \\
\text { Florida-Friendly Landscaping } \\
\text { land Program), } \\
\text { general public }\end{array}$ & https://assessment.ifas.ufl.edu \\
\hline \multicolumn{4}{|c|}{$\begin{array}{l}\text { *The UF/IFAS Assessment is nonregulatory to the general public, but all UF/IFAS faculty, staff, and affiliated programs (Florida Master Gardener } \\
\text { Volunteer Program, Florida-Friendly Landscaping }{ }^{\text {TM }} \text { Program) must adhere to and reference the conclusions of the UF/IFAS Assessment. High- } \\
\text { risk or invasive species may not be recommended by UF/IFAS faculty or staff. In rare cases, "specified and limited uses" may be approved by the } \\
\text { UF/IFAS Invasive Plant Working Group for certain high-risk or invasive species. }\end{array}$} \\
\hline
\end{tabular}

